\title{
Donepezil: A review of the recent structural modifications and their impact on anti-Alzheimer activity
}

\author{
Noor ul Amin Mohsin ${ }^{\circledR 1}$, MatloobAhmad² \\ ${ }^{1}$ Department of Pharmaceutical Chemistry, Faculty of Pharmaceutical Sciences, Government College University Faisalabad, \\ Pakistan, ${ }^{2}$ Department of Chemistry, Government College University Faisalabad, Pakistan
}

\begin{abstract}
Alzheimer disease (AD) is characterized by a low level of acetylcholine, beta-amyloid (A $\beta$ ) aggregation and oxidative stress. Donepezil is the core medicine used for the treatment of AD. Various structural modifications of donepezil have been carried out. Benzylpiperidine part of donepezil has been replaced with benzylpyridine, pyridyl methylpiperidine, benzylpiperazine, pyrimidyl piperazine. These derived molecules showed promising activities as anti-Alzheimer agents. Replacement of indanone part by other heterocyclic rings such as pyridine resulted in the formation of compounds which exhibited monoamine oxidase (MAO) as well as acetylcholinesterase (AChE) inhibition. Propargylamine containing derivatives displayed AChE as well as MAO inhibition properties. Attachment of donepezil with natural compounds like ferulic acid, flavonoids, and curcumin showed antioxidant activities in addition to inhibition of the AChE. Benzylpiperidine and benzylpiperazine have also been combined with condensed heterocyclic rings and these compounds displayed promising anti-Alzheimer properties. This review highlights the important structural modifications of donepezil and their influence on biological activities as antiAlzheimer agents.
\end{abstract}

Keywords: Acetylcholinesterase (AChE). Butyrylcholinesterase (BuChE). Benzylpiperidine. Indanone. Hybrid compounds.

\section{INTRODUCTION}

The Alzheimer disease (AD) is a neurodegenerative disorder and is characterized by premature senile mental deterioration. It mainly affects the elder people aged above 65 years (Naj et al., 2011). At present, 36 million people are affected due to this disease all over the world and according to some estimates, this number will increase up to 115 million in 2050 (Bolea et al., 2011). Characteristic features of this disease are memory loss, cognitive impairment, behavioural changes and eventual death (Scarpini, Scheltens, Feldman, 2003). Low level of acetylcholine is one of the major causes in the development and progress of this disease (Talesa, 2001). Alteration in the dopaminergic, serotoninergic and monoaminergic neurotransmission also contribute to some symptoms of Alzheimer disease. Beta-amyloid (A $\beta)$ aggregation and oxidative stress are the other causes of this disease (Gella, Durany, 2009; Selkoe, Podlisny, 2002). Accumulation of

\footnotetext{
*Correspondence: N. A. Mohsin. Department of Pharmaceutical Chemistry, Faculty of Pharmaceutical Sciences, Government College University Faisalabad, Pakistan. Phone: 00923330929149. E-mail: noorulaminmohsin@yahoo.com
}

metal ions also results in fatal neurologic disorders and it is closely associated with abnormal A $\beta$ plaques (Bush, 2008). Donepezil, rivastigmine, and galanthamine are the drugs which increase acetylcholine concentration by inhibiting cholinesterases and are effective in the treatment of AD (Birks, Harvey, 2006; Leon, Garcia, Marco-Contelles, 2013). An $N$-methyl- $D$-aspartate receptor antagonist, memantine is also approved for the treatment of this disease (David et al., 2012). Donepezil is a selective inhibitor of AChE and this drug was approved for the treatment of AD in 1996 (Doody, Cummings, Farlow, 2012). Donepezil is a well tolerated and is most effective AChE inhibitor without causing hepatotoxicity. The benzylic portion of donepezil combines with the catalytic anionic site (CAS) and dimethoxy indanone part combines with the peripheral anionic site (PAS) of AChE enzyme (Cheung et al., 2012). The AD is very complex in nature and involves many factors. Therefore, a drug molecule which interacts with a single receptor or enzyme is not sufficient for the treatment of this disease. Hybrid molecular strategy, in which the pharmacophoric parts of two drugs are combined in a single molecule, 
is widely being used for designing the new donepezil derivatives (Leon et al., 2013). Over the last couple of years, a number of donepezil derivatives have been prepared and evaluated as anti-Alzheimer agents. To find the new derivatives, $N$-benzyl piperidinium and 5,6-dimethoxyindanone parts of donepezil have been attached as well as replaced by various other pharmacophores. In this review, an attempt has been made to summarize these derivatives on the basis of chemical structures and their biological activities as anti-Alzheimer agents.

\section{DONEPEZIL DERIVED COMPOUNDS}

Donepezil molecule comprises benzylpiperidine part which is connected to dimethoxy indanone through methylene group (Figure 1). It is used as a racemic mixture. Various structural modifications of this drug have been carried out and they are described in the following sections.

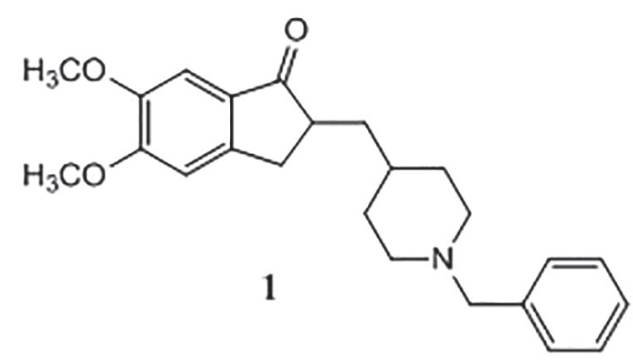

FIGURE 1 - Structural formula of donepezil.

\section{Benzylpiperidine, benzylpyridine, pyridyl methylpiperidine fragments attached to indanone}

Costanzo et al. (2016) carried out the synthesis of donepezil derivatives in which benzylpiperidine and indanone part were connected through the double bond. Compounds $\mathbf{2}$ (Figure 2) and $\mathbf{3}$ showed the most active inhibition of human erythrocytes $\mathrm{AChE}$ having $\mathrm{IC}_{50}$ values of $0.058 \pm 0.033 \mu \mathrm{M}$ and $0.043 \pm 0.007$ $\mu \mathrm{M}$ respectively. These compounds were found to be selective for AChE as compared to butyrylcholinesterase (BuChE) with selectivity values of 81 and 132 for compounds 2 and $\mathbf{3}$ respectively (Costanzo et al., 2016). Azzouz et al. synthesized bioxidiazable prodrugs of donepezil in which $N$-benzylpyridinium quaternary amine fragment was attached to indanone, tetralone and acetophenone fragments. Prominent activity was displayed by $N$-benzylpyridinium quaternary amine having the indanone ring. Compound 4 showed prominent inhibition of human AChE enzyme having an $\mathrm{IC}_{50}$ value of $0.36 \mathrm{nM}$. Docking studies of compound 4 showed that indanone part interacted with PAS while $\mathrm{N}$-benzyl group interacted with CAS of AChE. Carbonyl group of indanone part formed hydrogen bonding with Phe295 of AChE (Azzouz et al., 2018). Lan et al. carried out the synthesis of new donepezil derivatives in which 5,6-dimethoxy indanone part of donepezil was conjugated with $\mathrm{N}$-benzylpyridinium moiety. Compound $\mathbf{5}$ presented activity as cholinesterase inhibitor having $\mathrm{IC}_{50}$ values of $1.9 \mathrm{nM}$ and $0.8 \mathrm{nM}$ for electric eel AChE and human AChE respectively. A $\beta$ aggregation inhibitory activity (53.7\%) and antioxidant activity ( 0.54 Trolox equivalent) were also demonstrated by this compound. Compound 5 was also found to be neuroprotective at the dose of 1.56-12.5 $\mu \mathrm{M}$. Compound 5 showed interaction with the CAS as well as with the PAS of AChE and showed the mixed type of inhibition (Lan et al., 2017). Wang et al. modified the benzyl group of donepezil with various other heterocyclic rings such as pyridine, quinoline and hydroxyquinoline and small groups were also introduced at these heterocyclic rings. Compound $\mathbf{6}$ exhibited prominent inhibition of the $\mathrm{AChE}$ having $\mathrm{IC}_{50}$ values of $85 \mathrm{nM}$ and $73 \mathrm{nM}$ for electric eel $\mathrm{AChE}$ and human AChE respectively. Compound 6 also inhibited the $A \beta_{1-42}$ aggregation (46.3\%) induced by copper $\left(\mathrm{Cu}^{+2}\right)$ and showed neuroprotective effects. Molecular modeling studies showed a strong binding interaction of this compound with the CAS and PAS of AChE (Wang et al., 2016). Renou et al. (2016) synthesized four donepezil derivatives in which benzyl group of donepezil was replaced by 3 -hydroxy pyridinaldoxime. Newly synthesized oxime derivatives showed the capacity to re-activate VX (an organophosphorous nerve reagent) and inhibited the human AChE better than the standard drug pralidoxime. Compound 7 showed the prominent activation of human BuChE (5 to 11 fold higher) as compared to pralidoxime (Renou et al., 2016). Zurek, Szymański and Mikiciuk-Olasik (2013) synthesized donepezil derivatives by incorporating hydrazine nicotinate to the indanone part. Derivatives in this series showed a higher affinity for AChE than BuChE. Compound 9 was the most active AChE inhibitor $\left(\mathrm{IC}_{50}=1.087 \times 10^{-5} \mu \mathrm{M}\right)$ and also showed selectivity (selectivity index $=248.776$ ) for this enzyme. An increased AChE inhition was observed by replacing piperidine with benzylpiperidine and the resulting compound 9 appeared to be more active than compound 8. Docking studies of compound 9 showed a binding score of -181.939 with AChE using cache software (Żurek, Szymański, Mikiciuk-Olasik, 2013). 


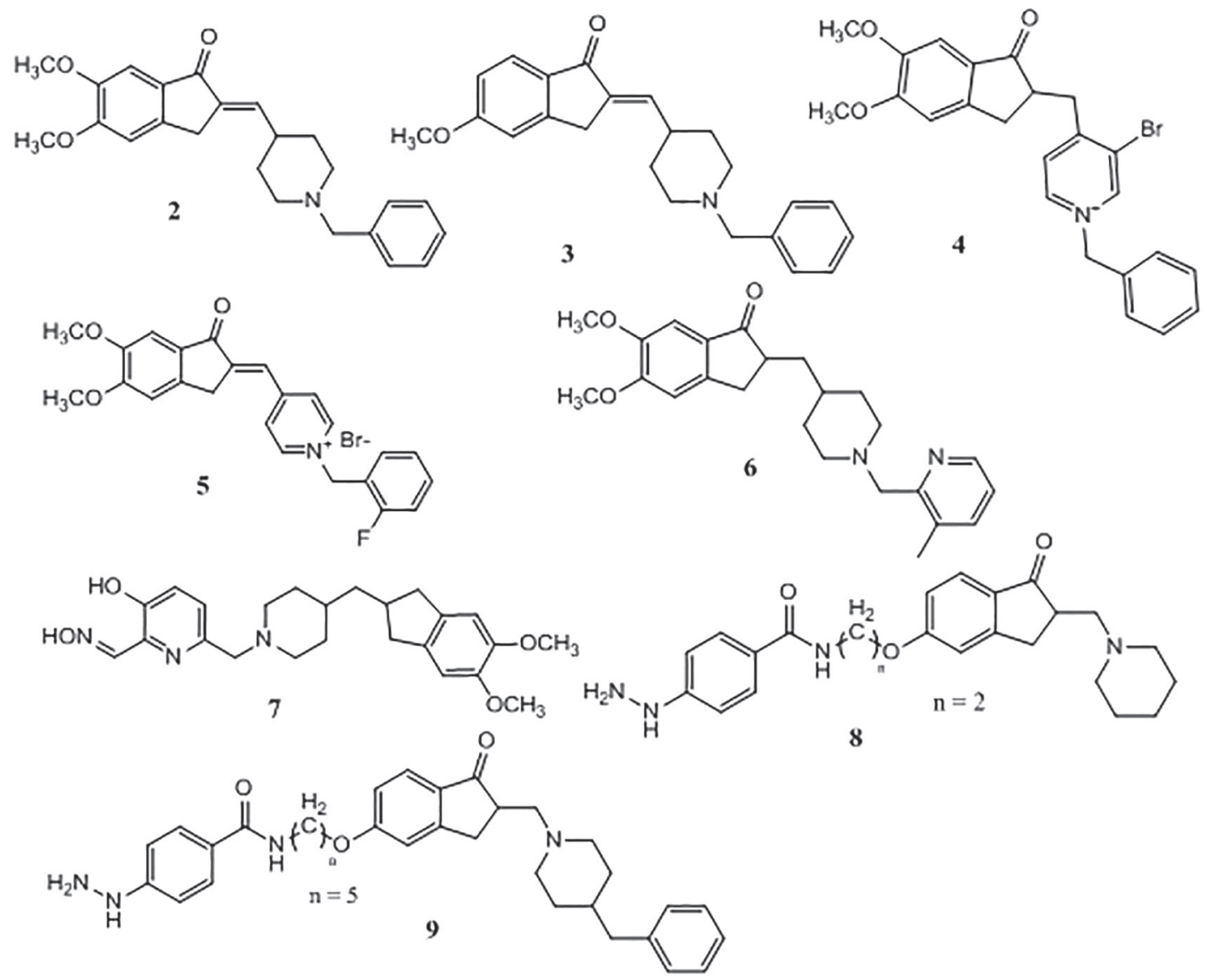

FIGURE 2 - Benzylpiperidine, benzylpyridine and pyridyl methypiperidine derivatives.

\section{Benzylpiperidine attached to aromatic rings other than indanone}

Özer et al. attached benzylpiperidine with the aromatic rings through an acylhydrazone group. These compounds were moderately active and nonselective as $\mathrm{AChE}$ and BuChE inhibitors. Compound $\mathbf{1 0}$ (Figure 3) was the most active in this series having $\mathrm{IC}_{50}$ values of $53.1 \pm 4.56 \mu \mathrm{M}$ and $67.3 \pm 5.24 \mu \mathrm{M}$ for $\mathrm{AChE}$ and $\mathrm{BuChE}$ enzymes respectively. Docking studies also showed the $\pi-\pi$ interaction with PAS and CAS site of human AChE. These compounds showed excellent inhibition (69-80\%) of the $\mathrm{A} \beta$ aggregation and have the potential for further modifications (Özer et al., 2013). N-benzylpiperidine-aryl-acylhydrazone derivatives were prepared by Viegas et al. (2018) and among these, compound 12 presented excellent inhibition of electrophorus electricus $\mathrm{AChE}$ with an $\mathrm{IC}_{50}$ value of $8.65 \mu \mathrm{M}$. Compounds $\mathbf{1 1}$ and 12 also exhibited the inhibition of COX-1 (51\% and $64 \%$ for 11 and 12 ) and COX-2 (65\% and 53\% for 11 and 12) enzymes. The interaction with COX enzymes was also confirmed by molecular docking studies. These compounds also showed neuroprotective ability
(Viegas et al., 2018). $N$-benzylpiperidine part of donepezil was attached with the beta-secretase (BACE-1) inhibitor through isophthalamide group to produce the new hybrid molecules. New molecules showed dual inhibition of AChE and BACE-1 enzymes and compound $\mathbf{1 3}$ was most prominent having $\mathrm{IC}_{50}$ values of $1.83 \pm 0.12 \mu \mathrm{M}$, $0.567 \pm 0.159 \mu \mathrm{M}$ for $\mathrm{AChE}$ and BACE-1 respectively. This compound also reduced the production of $A \beta$ $\left(\mathrm{IC}_{50}=98.7 \mathrm{nM}\right)$ and showed protection against hydrogen peroxide $\left(\mathrm{H}_{2} \mathrm{O}_{2}\right)$ induced cytotoxicity ( $\mathrm{Zhu}$ et al., 2009). In 2017 attached the optical isomers of glutamic acid (D and L glutamic acid) with $N$-benzylpiperidine part of donepezil. L-glutamine derivatives were found to be more active than D-glutamine. Compound 14 showed prominent activity having $\mathrm{IC}_{50}$ values of $4.99 \pm 0.16 \mu \mathrm{M}$ and $0.40 \pm 0.02 \mu \mathrm{M}$ for $\mathrm{AChE}$ and $\mathrm{BuChE}$ respectively. Compound 14 contains carboxy benzyl side chain (Monjas et al., 2017).

\section{Benzylpiperidine attached with heterocyclic rings}

Samadi et al. (2012) synthesized new pyridonepezil derivatives by linking the $N$-benzylpiperidine part 
<smiles>CCOc1ccc(/C=N/NC(=O)CN2CCC(Cc3ccccc3)CC2)cc1</smiles>

10<smiles>[X]c1ccc(/C=N/NC(=O)c2ccc(CN3CCCC(O)C3)cc2)cc1</smiles>

$11 \mathrm{X}=\mathrm{Cl}$

$12 \quad X=F$<smiles></smiles>

FIGURE 3 - Benzylpiperidine attached with aromatic rings.

of donepezil and 2-aminopyridine heterocyclic ring. Compounds $15\left(\mathrm{IC}_{50}=0.0094 \pm 0.0004 \mu \mathrm{M}\right)$ (Figure 4) and $\mathbf{1 6}\left(\mathrm{IC}_{50}=0.070 \pm 0.005 \mu \mathrm{M}\right)$ showed prominent $\mathrm{AChE}$ inhibitory activity as well as selectivity (S.I. $=703,24$ for compound 15 and 16 respectively) for human AChE than human BuChE (Samadi et al., 2012). An year later, Samadi et al. (2013) synthesized 6-chloropyridonepezil derivatives and compound $\mathbf{1 7}$ displayed the most active inhibition of human $\mathrm{AChE}\left(\mathrm{IC}_{50}=0.013 \pm 0.002 \mu \mathrm{M}\right)$ and human $\mathrm{BuChE}\left(\mathrm{IC}_{50}=8.13 \pm 0.0004 \mu \mathrm{M}\right)$. These compounds showed the ability to cross the BBB. Docking studies revealed that compound $\mathbf{1 7}$ interacted with the CAS and PAS of the AChE (Samadi et al., 2013). Li et al. (2016) synthesized donepezil derivatives by linking the benzylpiperidine part of donepezil with benzamide and picolinamide moiety from an MAO inhibitor lazabemide. These compounds displayed AChE, BuChE, MAO-A and MAO-B inhibitory activities. Compound 18 presented the most potent inhibition of cholinesterases having $\mathrm{IC}_{50}$ values of $0.220 \mu \mathrm{M}, 1.23 \mu \mathrm{M}$ and $0.454 \mu \mathrm{M}$ for electric eel AChE, equine BuChE and human $\mathrm{AChE}$ respectively. This compound also showed inhibition of MAO-A and MAO-B having $\mathrm{IC}_{50}$ values of $3.14 \mu \mathrm{M}$ and $13.4 \mu \mathrm{M}$. Compound 18 showed the capacity to cross the BBB and also exhibited metal chelating property. Docking studies of compound $\mathbf{1 8}$ with MAO-B demonstrated that 5-chloropicolinamide interacted with hydrophobic pocket while the $N$-benzylpiperidine bound via $\pi$-cation interaction with MAO-B (Li et al., 2016).

\section{Indanone derivatives having aromatic and heterocyclic rings}

Yerdelen et al. (2015) attached the indanone part of donepezil with substituted aromatic rings through the amide group. Compound 19 (Figure 5) was the most prominent<smiles>N#Cc1cc(C#N)c(NC2CCN(Cc3ccccc3)CC2)nc1N</smiles><smiles>N#Cc1cc(C#N)c(NCCCCC2CCN(Cc3ccccc3)CC2)nc1Cl</smiles><smiles>O=C(NCCC1CCN(Cc2ccccc2)CC1)c1ccc(Cl)cn1</smiles>

FIGURE 4 - Benzylpiperidine attached with heterocyclic rings. 
inhibitor $\left(\mathrm{IC}_{50}=0.08 \pm 1.83 \mu \mathrm{M}\right)$ of $\mathrm{AChE}$ and it was most selective $(\mathrm{SI}=40.1)$ for this enzyme. Compound 19 exhibited the most prominent inhibition of $\mathrm{A} \beta(55.3 \%$ at $25 \mu \mathrm{M}$ ) aggregation. Compound 19 also showed bonding interactions with CAS and PAS in the AChE binding sites (Yerdelen et al., 2015). Meng et al. synthesized new donepezil derivatives in which the indanone part was connected to the pyridine ring through the double bond. Upon evaluation as $\mathrm{AChE}$ and $\mathrm{BuChE}$ inhibitor, compound 20 showed the most prominent inhibition of AChE having an $\mathrm{IC}_{50}$ value of $0.0018 \mu \mathrm{M}$ and selectivity (5248.6) for $\mathrm{AChE}$ as compared to BuChE. It was more potent than the standard drugs donepezil and tacrine. Compound 20 also showed prominent metal chelating ability (Meng et al., 2012). Nan DD et al. synthesized 6-methoxy indanone derivatives and evaluated them as probes for $\beta$ amyloid plaques. Iodine ( ${ }^{125} I$ ) radiolabelled derivative (21) showed better binding to the $\beta$ amyloid plaque, higher uptake in the brain and rapid clearance. Compound 21 also showed better penetration across BBB having a partition coefficient of 3.45 (Nan et al., 2016). Rizzo et al. (2010) attached indanone part of donepezil to the phenyl- $N$-methylbenzylamino fragment from AP2238. Compound 22 showed prominent inhibition $(46.8 \pm 2.0 \%)$ of $\mathrm{AChE}$ induced $\mathrm{A} \beta$ aggregation. Derivatives $\mathbf{2 3}$ and $\mathbf{2 4}$ showed prominent AChE inhibitory activities having $\mathrm{IC}_{50}$ values of $0.056 \pm 0.003 \mu \mathrm{M}$ and $0.052 \pm 0.002$ $\mu \mathrm{M}$ respectively. These compounds contain pentamethylene chain connecting diethylamine and piperidine group with the tetralone part. Compounds $\mathbf{2 3}$ and $\mathbf{2 4}$ also showed the $\mathrm{A} \beta$ aggregation inhibition induced by $\mathrm{AChE}$ having the inhibitory values of $42.9 \pm 0.8 \%$ and $48.3 \pm 0.9 \%$. Compounds 23 and 24 also inhibited the self-aggregation of $A \beta$. The long alkyl chain of these compounds having amino group showed a better interaction with PAS (Rizzo et al., 2010). Mishra et al. carried out the synthesis of new 5,6-dimethoxy indanone-piperazine derivatives in which<smiles>COc1cc2c(cc1OC)C(=O)C(C(=O)Nc1ccccc1F)C2</smiles><smiles>COc1cc2c(cc1OCCN1CCCCC1)C(=O)/C(=C\c1ccncc1)C2</smiles><smiles>COc1cc2c(cc1N)C/C(=C\c1ccc(N(C)C)cc1)C2=O</smiles><smiles>COc1cc2c(cc1C(C)(C)N1CCCCC1)C/C(=C\c1ccc(CN(C)Cc3ccccc3)cc1)C2=O</smiles>

22<smiles>[R][R4]Oc1ccc2c(c1)CC/C(=C\c1ccc(CN(C)Cc3ccccc3)cc1)C2=O</smiles><smiles>[R]c1cc2c(cc1[R])C(=O)/C(=C\c1ccc(N3CCN([R1])CC3)cc1)C2</smiles>

23-24 $23 \mathrm{R}=$ Diethylamine $24 \mathrm{R}=$ Piperidine

26<smiles>CCc1ccc(N2CCN(c3ncccn3)CC2)cc1</smiles>
$\begin{array}{ccc}\mathrm{R}_{1}= & \mathrm{R}_{2}= & \mathrm{R}_{3}= \\ \mathbf{2 7}\left(\mathrm{CH}_{3}\right)_{2} \mathrm{NCH}_{2} \mathrm{CH}_{2} & \mathrm{OCH}_{3} & \mathrm{OCH}_{3} \\ \mathbf{2 8}\left(\mathrm{CH}_{3}\right)_{2} \mathrm{NCH}_{2} \mathrm{CH}_{2} \mathrm{CH}_{2} & \mathrm{OCH}_{3} & \mathrm{H} \\ \mathbf{2 9}\left(\mathrm{CH}_{3}\right)_{2} \mathrm{NCH}_{2} \mathrm{CH}_{2} \mathrm{CH}_{2} & \mathrm{H} & \mathrm{OCH}_{3} \\ \mathbf{3 0}\left(\mathrm{CH}_{3}\right)_{2} \mathrm{NCH}_{2} \mathrm{CH}_{2} \mathrm{CH}_{2} & \mathrm{OCH}_{3} & \mathrm{OCH}_{3}\end{array}$

FIGURE 5 - Indanone derivatives having aromatic and heterocyclic rings. 
structural parts of donepezil, curcumin and piperazine ring were combined to produce new molecules. Compounds $\mathbf{2 5}$ and $\mathbf{2 6}$ showed excellent AChE inhibitory potential having $\mathrm{IC}_{50}$ values of $0.034 \pm 0.002 \mu \mathrm{M}$ and $0.025 \pm 0.001$ $\mu \mathrm{M}$ and showed selectivity ( $\mathrm{SI}=28.5$ and 97.3 for $\mathbf{2 5}$ and 26 respectively) for $\mathrm{AChE}$ than $\mathrm{BuChE}$. Compounds 25 and $\mathbf{2 6}$ showed excellent inhibition of the $\mathrm{A} \beta$ aggregation $(80.4 \pm 1.08 \%, 81.6 \pm 0.78 \%$ for $\mathbf{2 5}$ and $\mathbf{2 6}$ respectively) and antioxidant $(3.89 \pm 0.01,2.34 \pm 0.03$ for $\mathbf{2 5}$ and $\mathbf{2 6}$ respectively) activities. Molecular docking studies showed that these compounds have good interaction with $\mathrm{AChE}$ and $A \beta$ peptide. Pyrimidine part of $\mathbf{2 6}$ binds through $\pi-\pi$ interaction with PAS of AChE while the indanone part forms the hydrophobic interaction with CAS (Mishra et al., 2017). Synthesis of new donepezil derivatives was carried out by Saglik et al. and their inhibitory effect on AChE was investigated. Compounds 27-30 displayed prominent inhibition of this enzyme (89.14-90.31\% inhibition) and were found to be nontoxic $\left(\mathrm{IC}_{50}=78-320 \mu \mathrm{M}\right)$ on NH/3T3 cell line. Side chains having another basic centre at the position \# 4 of piperazine ring produced compounds with significant activity. Molecular docking studies also showed the interaction between these derivatives and targeted enzyme. Long chains of these compounds increased the van der Waals interactions with target enzyme (Sağlık, Ilgın, Özkay, 2016). Ismail et al. used indole molecule as the bioisosteric replacement of indanone part of donepezil. These compounds exhibited prominent AChE inhibitory
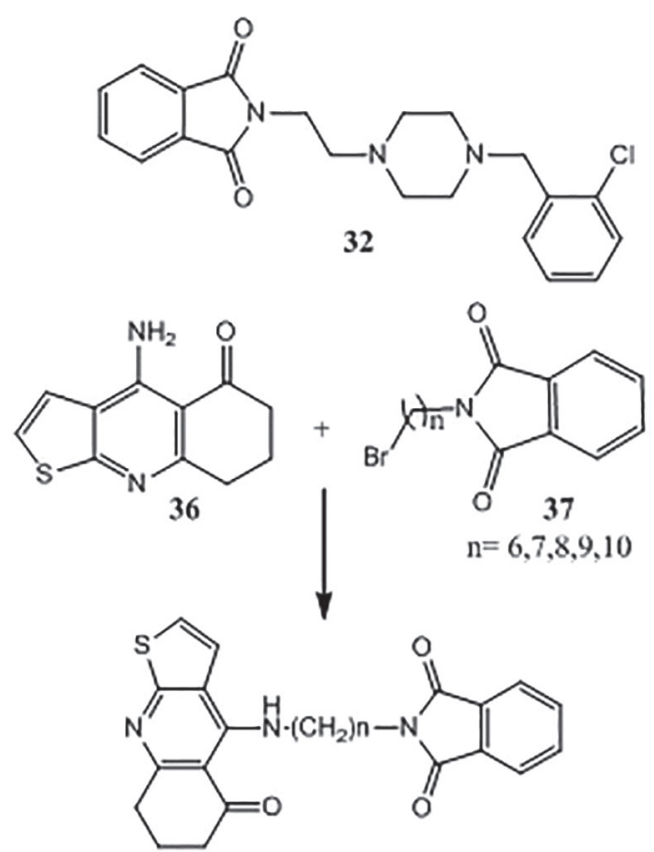

$39,40,41,42,43$

$\mathrm{n}=6,7,8,9,10$ activity and compound $\mathbf{3 1}$ was the most active (55\% inhibition) derivative in this series. Molecular docking studies of this compound also showed good energy score $(-23.4711 \mathrm{kcal} / \mathrm{mol})$ in the active site of AChE. This was related to the additional 3-oxo and 2-fluorobenzyl groups in this compound (Ismail et al., 2012a).

\section{Phthalimide derivatives}

Mohammadi-Farani et al. (2013) carried out the synthesis of donepezil derivatives in which the phthalimide ring was used in place of indanone part of donepezil. It was connected to benzylpiperazine through an alkyl chain. In this series, compound 32 (Figure 6) was the most prominent inhibitor of AChE having an $\mathrm{IC}_{50}$ value of $0.91 \mu \mathrm{M}$. This compound contains ortho chloro substituent attached to the phenyl ring. Therefore electron withdrawing groups increased the activity of phthalimide derivatives. The molecular modeling study of this compound showed that piperazine, phthalimide and benzyl group occupied the same position at the AChE as the piperidine, indanone and benzyl group of donepezil (Mohammadi-Farani et al., 2013). Ignasik et al. (2012) synthesized 2-(diethylaminoalkyl)-isoindoline-1,3-dione derivatives in which the phthalimide fragment was used as a substituent to indanone part of donepezil. Dialkylamine was used as a part which binds with the CAS. Compound $\mathbf{3 5}$ was the most prominent derivative in this series having

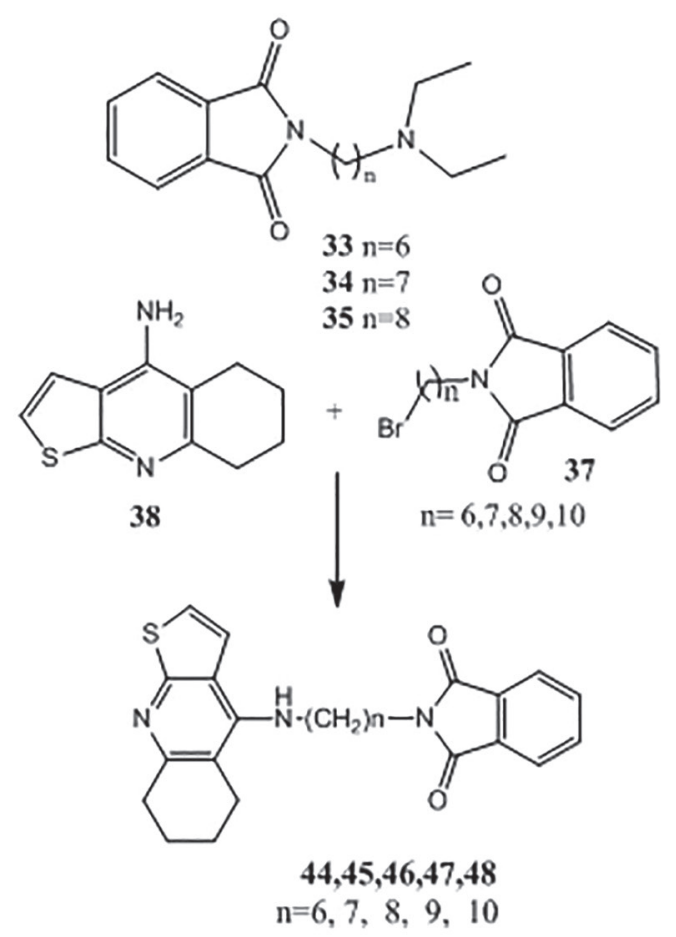

FIGURE 6 - Phthalimide derived compounds. 
an $\mathrm{IC}_{50}$ value of $0.9 \mu \mathrm{M}$ for $\mathrm{AChE}$. It contains an alkyl chain of eight methylene units. Compounds 33 and 34 also showed the promising and selective inhibition of $\mathrm{AChE}$ having $\mathrm{IC}_{50}$ values of $1.2 \mu \mathrm{M}$ and $1.1 \mu \mathrm{M}$. Docking studies of these compounds also showed interaction with $\mathrm{AChE}$ only. Compounds $\mathbf{3 3}$ and $\mathbf{3 4}$ also exhibited the inhibition (33.8\% and $39.4 \%$ for $\mathbf{3 3}$ and $\mathbf{3 4}$ ) of $\mathrm{A} \beta$ aggregation (Ignasik et al., 2012). Sang et al. (2017) carried out the synthesis of new molecules comprising phthalimide and 4 -amino tetrahydrothienoquinoline. The reaction was done by direct alkylation of $\mathbf{3 7 a - e}$ with $\mathbf{3 6}$ and $\mathbf{3 8}$. These compounds have the potential for evaluation as AChE inhibitors (Song, Jo, 2009).

\section{Donepezil and ferulic acid hybrid molecules}

Ferulic acid is a phenolic compound which is found abundantly in plants. Donepezil and ferulic acid hybrids compounds were synthesized by Benchekroun et al. Resultant molecules showed prominent antioxidant activity and also showed selective inhibition of equine BuChE. Compounds 49 (Figure 7) and $\mathbf{5 0}$ were most active inhibitors of the BuChE having $\mathrm{IC}_{50}$ values of $10.39 \pm 0.48 \mathrm{nM}$ and $20.1 \pm 1.9 \mathrm{nM}$ respectively. Compounds 49 and 50 exhibited oxygen radical absorbing capacity of $8.71 \pm 0.20 \mu \mathrm{mol}$ and $8.48 \pm 0.33 \mu \mathrm{mol}$ respectively. These compounds contain ethylene and propylene linkers respectively and both of them contain melatonin as part of their structure (Benchekroun et al., 2015). Dias et al. also synthesized donepezil-ferulic acid hybrid molecules by combining their pharmacophores. Compound $\mathbf{5 1}$ exhibited prominent activity against $\mathrm{AChE}$ having an $\mathrm{IC}_{50}$ value of $0.46 \mu \mathrm{M}$. Molecular docking studies showed the interaction of this compound with $\mathrm{AChE}$ with the docking score of -16.129 with free $\mathrm{AChE}$ and -16.956 with acetylated AChE. Phenyl ring, the nitrogen atom of piperidine ring, a carbonyl group and 2-methoxyphenol ring of this compound interacted with AChE enzyme. Compound $\mathbf{5 1}$ also showed anti-inflammatory potential by inhibiting COX-1, COX-2 and lipooxygenase (5-LOX) enzymes. This compound also showed metal chelating capacity with certain metals along with neuroprotective effects (Dias et al., 2017). Sang et al. carried out the synthesis of ferulic acid- $O$-alkylamine derivatives by attaching the benzylpiperidine part of donepezil with ferulic acid and secondary amines by using methylene spacer. These compounds showed BuChE inhibitory and antioxidant activity. Compound $\mathbf{5 2}$ appeared as the most excellent inhibitor of $\mathrm{BuChE}\left(\mathrm{IC}_{50}=0.021 \mu \mathrm{M}\right)$ and $\mathrm{AChE}$ $\left(\mathrm{IC}_{50}=2.13 \mu \mathrm{M}\right)$. Compound $\mathbf{5 2}$ also showed the inhibition of $\mathrm{A} \beta(50.8 \pm 0.82 \%)$ aggregation. It also showed the ability to cross the BBB as well as less toxicity. Molecular modeling studies of compound $\mathbf{5 2}$ presented cation- $\pi$ interaction, $\pi-\pi$ interactions and hydrophobic interactions with $\mathrm{BuChE}$ but only hydrophobic interactions were observed with $\mathrm{AChE}$ which may be the reason for its selectivity for BuChE (Sang et al., 2017). Xu et al. (2016) combined the pharmacophores of donepezil and ferulic acid to produce new hybrid molecules. Compound $\mathbf{5 3}$ displayed the prominent inhibition of electric eel $\mathrm{AChE}$ and equine BuChE having $\mathrm{IC}_{50}$ values of $0.398 \mu \mathrm{M}$ and $0.976 \mu \mathrm{M}$ respectively. Significant antioxidant activity (1.78 Trolox equivalents) was also observed for this compound. Molecular docking studies showed that compound $\mathbf{5 3}$ binds with PAS by polar contacts of phenyl propanoid group and with CAS by the $\pi-\pi$ interaction of the phenyl ring (Xu et al., 2016).

\section{Donepezil and tacrine hybrid compounds}

Tacrine was the first compound used for the treatment of AD but it was withdrawn from the market due to the toxic side effects. 7-Methoxytacrine is a less toxic derivative of tacrine (Soukup et al., 2013). Alonso et al.<smiles>COc1ccc2[nH]cc(CCNCCN(C(=O)/C=C/c3ccc(O)cc3)C(=O)C3CCN(Cc4ccccc4)CC3)c2c1</smiles><smiles>C=CC=CN1CCc2ccccc2C1</smiles><smiles>COc1cc(/C=C/C(=O)OCC2CCN(Cc3ccccc3)CC2)ccc1O</smiles>

FIGURE 7 - Donepezil and ferulic acid hybrid molecules. 
reported the synthesis of donepezil and tacrine hybrid compounds in which indanone part of donepezil was replaced by phthalimide ring. These derivatives showed more selectivity for $\mathrm{AChE}$ as compared to BuChE. Compounds 54 and 55 (Figure 8) displayed excellent inhibition of the AChE enzyme having $\mathrm{IC}_{50}$ values of $2.8 \mathrm{nM}$ and $2.4 \mathrm{nM}$ respectively. These compounds have the linker chain length of 9 and 12 methylene units between 9-aminoacridine and phthalimide scaffold. Molecular modeling of compounds 54 and 55 revealed that tetrahydroacridine/acridine rings of these compounds interacted with the catalytic site. Phthalimide ring attached with the peripheral site of AChE. Aromatic ring nitrogen formed hydrogen bonding while the chlorine atom interacted with hydrophobic pocket (Alonso et al., 2005). Synthesis of donepezil and tacrine hybrid molecules was carried out by Camps et al. in which the 5,6-dimethoxy- 2-(4-piperidylmethyl) 1-indanone piperidine part of donepezil was attached to the tacrine. These compounds showed prominent inhibition of $\mathrm{AChE}$ and $\mathrm{BuChE}$ enzymes. Compound $\mathbf{5 6}$ was most potent having an $\mathrm{IC}_{50}$ value of $0.27 \pm 0.03 \mathrm{nM}$ for human $\mathrm{AChE}$. Compound $\mathbf{5 7}$ was the most prominent inhibitor $(65.9 \pm 2.5 \%$ inhibition) of $\mathrm{A} \beta$ aggregation. Tetrahydroacridine ring of compound 56 attached with the catalytic site of AChE while ring nitrogen formed hydrogen bonding with the carbonyl oxygen of His 447 of enzyme and chlorine atom occupies the hydrophobic pocket (Camps et al., 2008). Sepsova et al . (2015) evaluated 7-methoxytacrine and donepezil hybrid molecules for their interaction with AChE, with muscarinic and nicotinic acetylcholine receptors and these compounds presented activity in the micromolar range. They also showed the capacity to penetrate into CNS. Compound $58\left(\mathrm{IC}_{50}=1.38 \pm 0.15 \mu \mathrm{mol} / \mathrm{litre}\right)$ was the most potent<smiles></smiles><smiles>[X]CNC(=O)CN1C(=O)c2ccccc2C1=O</smiles>

\section{$55 \mathrm{X}=\left(\mathrm{CH}_{2}\right)_{2} \mathrm{NCH}_{3}$}

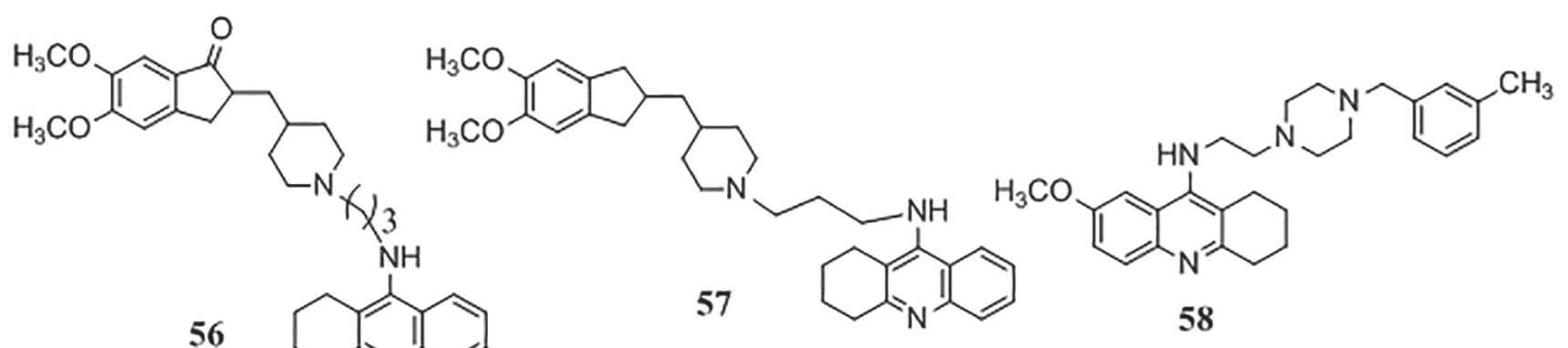<smiles>ClC1=CC2=CCCC(=N2)CC1</smiles><smiles>[R]c1ccc(CN2CCN(CCNc3c4c(nc5ccc(OC)cc35)CCCC4)CC2)cc1</smiles>

$60 \mathrm{R}=\mathrm{CF}_{3}$<smiles>COc1ccc2nc3c(c(NCCN4CCN(Cc5cccc(Br)c5)CC4)c2c1)CCCC3</smiles>

FIGURE 8 - Hybrid molecules comprising donepezil and tacrine fragments. 
AChE inhibitor and showed a mixed type of inhibition i.e. competitive and non-competitive (Sepsova et al., 2015). Hybrid molecules comprising 7-methoxytacrine and donepezil were synthesized by Korabecny et al. (2014) in which benzylpiperazine acted as isostere of the benzylpiperidine fragment of donepezil. The synthesized compounds exhibited excellent cholinesterase inhibitory activity against human and animal cholinesterases. Compounds 59, 60, 61 were prominent having $\mathrm{IC}_{50}$ values of $1.12 \pm 0.11 \mu \mathrm{M}, 1.16 \pm 0.22 \mu \mathrm{M}$ and $1.94 \pm 0.26 \mu \mathrm{M}$ against human $\mathrm{AChE}$ while $\mathbf{6 2}$ was the most active inhibitor of human BuChE with an $\mathrm{IC}_{50}$ value of $0.42 \pm 0.01 \mu \mathrm{M}$. Molecular modeling investigations showed the interaction of these derivatives with the CAS and PAS of the AChE. 4-Bromophenyl group of compound $\mathbf{5 9}$ forms a new $\pi$ - $\pi$ interaction with enzyme and showed a binding energy of $-13.8 \mathrm{kcal} / \mathrm{mol}$ (Korabecny et al.,2014). Misik et al. (2015) evaluated 7-methoxytacrine and $N$-benzylpiperazine hybrid molecules as AChE inhibitors and compound 63 showed prominent inhibition (11.3\%) of this enzyme as compared to donepezil (41\%). Compound 63 contains benzylpiperazine group in place of benzylpiperidine fragment of donepezil (Misik et al., 2015).

\section{Donepezil hybrids with natural compounds}

Compounds isolated from natural sources serve as lead compounds for new drug development (Koehn, Carter, 2005). Natural compounds have been combined with benzylpiperidine part of donepezil and these molecules demonstrated anti-Alzheimer activities. Xie et al. combined $N$-benzylpiperidine part of donepezil with coumarin to produce new molecules having cholinesterase and MAO-B inhibitory activities. Compound 64 (Figure 9) appeared as the most active inhibitor of human $\mathrm{AChE}$ and human $\mathrm{BuChE}$ with $\mathrm{IC}_{50}$ values of $1.37 \pm 0.05 \mu \mathrm{M}$ and $1.98 \pm 0.08 \mu \mathrm{M}$ respectively. Compound 64 also showed inhibition of the MAO-B with an $\mathrm{IC}_{50}$ value of $2.62 \pm 0.81 \mu \mathrm{M}$. Molecular modeling studies showed that phenyl group of coumarin ring binds with PAS through $\pi-\pi$ interaction and carbonyl oxygen forms hydrogen bonding with PAS. $N$-benzylpiperidine forms $\pi-\pi$ interaction with CAS of AChE. Compound $\mathbf{6 4}$ showed the capacity to cross the BBB and was found non-toxic for HepG2 cell line (Xie et al., 2016). Yan et al. synthesized new molecules by combining pharmacophores of donepezil and curcumin. Compound $\mathbf{6 5}$ exhibited the prominent inhibition of $\mathrm{AChE}$ and it also showed selectivity for $\mathrm{AChE}$ $\left(\mathrm{IC}_{50}=0.187 \pm 0.015 \mu \mathrm{M}\right)$ than $\mathrm{BuChE}\left(\mathrm{IC}_{50}=12.4 \pm 1.03\right.$ $\mu \mathrm{M})$. Compound 65 also showed inhibition $(45.3 \pm 3.58 \%)$ of $\mathrm{A} \beta$ aggregation. This compound also penetrated $\mathrm{BBB}$ $(\mathrm{Pe}=11.85 \pm 1.00)$ and showed antioxidant activity (3.07 $\pm 0.04 \mu \mathrm{mol})$ (Yan et al., 2017). Shen et al. (2009) linked $N$-benzylpiperidine part of donepezil to various flavonoids to produce the new hybrid molecules. Among these derivatives, Compound $\mathbf{6 6}$ exhibited the most effective inhibition of $\mathrm{AChE}$ with an $\mathrm{IC}_{50}$ value of 0.093 $\mu \mathrm{M}$. Compound 66 showed increased selectivity for $\mathrm{AChE}$ as compared to BuChE. Compounds having oxygen linker were found to be more active as compared to the methoxy group. Molecular docking investigations of this compound with $\mathrm{AChE}$ showed that isoflavone part<smiles>COc1ccc(C(=O)CC(=O)CC2CCN(Cc3ccccc3)CC2)cc1OC</smiles>

FIGURE 9 - Donepezil hybrids molecules with natural compounds. 
of compound $\mathbf{6 6}$ joined the peripheral pocket through hydrophobic interactions. Two hydrogen bonds were also observed for this compound with Ser286 and Arg289. Compound 66 showed a binding free energy of -22.28 $\mathrm{kcal} / \mathrm{mol}$ (Shen et al., 2009). Rodriguez-Franco et al. (2005) also linked benzylpiperidine and benzylpyridine to 8-substituted xanthine derived from theophylline. Methoxymethyl group was used as a linker group between these two pharmacophores. These compounds exhibited $\mathrm{AChE}$ and BuChE inhibitory activities. Compound $\mathbf{6 7}$ showed prominent activity in this series presenting an $\mathrm{IC}_{50}$ value of $0.1 \pm 0.01 \mu \mathrm{M}$ for AChE. Compound $\mathbf{6 8}$ was the most active inhibitor of the $\mathrm{BuChE}$ with an $\mathrm{IC}_{50}$ value of $0.4 \pm 0.01 \mu \mathrm{M}$. Therefore it was noted that compounds having benzylpyridine part showed better interaction with $\mathrm{AChE}$. The additional aromatic ring interacted with the aromatic amino acid of AChE (Rodríguez-Franco et al., 2005).

\section{Donepezil derivatives having propargylamine group}

The presence of propargylamine group in certain drugs such as rasagiline and ladostigil confer neuroprotective, antiapoptotic and $A \beta$ aggregation inhibitory properties (Bar-Am et al., 2010). BautistaAguilera et al. carried out the synthesis of new donepezil and indole hybrid molecules as anti-Alzheimer agents. In this compound, benzylpiperidine was attached to the position \# 5 of indole through three methylene units and propargylamine group was attached at position \# 2 of the indole ring. Compound 69 (Figure 10) was found to be the most potent agent in this class. It showed potent human MAO-A $\left(\mathrm{IC}_{50}=0.0055 \pm 0.0014 \mu \mathrm{M}\right)$ inhibitory activity as well as selectivity as compared to human MAO-B $\left(\mathrm{IC}_{50}=0.15 \pm 0.031 \mathrm{nM}\right)$. Compound 69 also exhibited $\mathrm{AChE}\left(\mathrm{IC}_{50}=0.19 \pm 0.01 \mu \mathrm{M}\right)$ and $\mathrm{BuChE}$

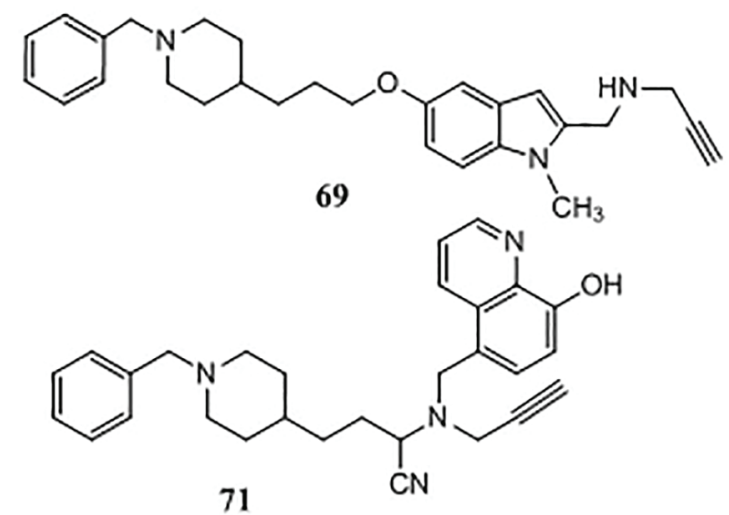

$\left(\mathrm{IC}_{50}=0.83 \pm 0.16 \mu \mathrm{M}\right)$ inhibitory activities. Docking studies with AChE showed that propargylamine interacted via $\pi-\pi$ bonding with Trp 86 . Phenyl ring interacted with the PAS and compound showed the binding free energy of $-11.9 \mathrm{kcal} / \mathrm{mol}$ (Bautista-Aguilera et al., 2014). Bolea et al. synthesized some multitarget molecules in which benzylpiperidine part of donepezil and indole propargylamine part of MAO inhibitor $N$-[(5-benzyloxy1-methyl-1 $H$-indol-2-yl)methyl]- $N$-methylprop-2yn-1-amine were conjugated. Resultant compounds showed the capacity to interact with cholinesterases and MAO enzymes. Compound $\mathbf{7 0}$ exhibited prominent activity having MAO-A $\left(\mathrm{IC}_{50}=5.2 \pm 1.1 \mathrm{nM}\right)$, MAO-B $\left(\mathrm{IC}_{50}=43 \pm 8 \mathrm{nM}\right), \operatorname{AChE}\left(\mathrm{IC}_{50}=0.35 \pm 0.01 \mathrm{nM}\right)$, $\mathrm{BuChE}\left(\mathrm{IC}_{50}=0.46 \pm 0.06 \mathrm{nM}\right)$ inhibitory activities. Compound 70 also showed the inhibition (32.4 $\pm 7.0 \%)$ of $A \beta$ aggregation. Molecular docking studies revealed that benzylpiperidine fragment attached with catalytic site and indole propargylamine part is stacked between aromatic rings with Trp279 and Tyr334. Propargylamine formed van der Waals interaction with phenyl ring of Tyr70 (Bolea et al., 2011). Wang et al. (2014) synthesized hybrid compounds in which structural parts of donepezil, propargylamine and 8-hydroxyquinoline were combined. Compound $\mathbf{7 1}$ was the most active compound and showed simultaneous inhibition of MAO-A and MAO-B presenting $\mathrm{IC}_{50}$ values of $6.2 \mu \mathrm{M}$ and $10.2 \mu \mathrm{M}$ respectively. Significant $\mathrm{AChE}\left(\mathrm{IC}_{50}=1.8 \pm 0.1 \mu \mathrm{M}\right)$ and $\mathrm{BuChE}\left(\mathrm{IC}_{50}=1.6 \pm 0.25 \mu \mathrm{M}\right)$ inhibitory values were also observed for this compound. Compound $\mathbf{7 1}$ also showed excellent pharmacokinetic properties and displayed less toxicity to HepG2 cell line. Compound $\mathbf{7 1}$ contains 8-hydroxyquinoline and $\mathrm{N}$-benzylpiperidine attached to the central propargylamine part having a nitrile group. This compound is a racemic mixture and both isomers showed binding at PAS and CAS of electric eel AChE (Wang et al., 2014). Later on, Wu et al. (2016) also

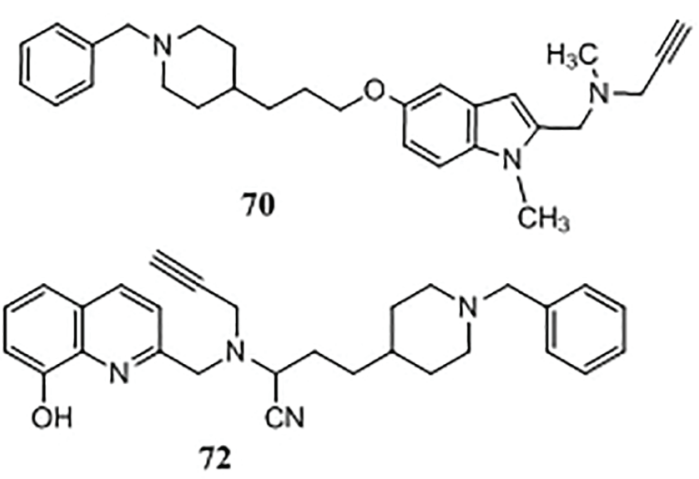

FIGURE 10 - Propargylamine derivatives of donepezil. 
combined propargylamine group with benzylpiperidine and quinoline to produce new hybrid molecules. Among these derivatives, compound $\mathbf{7 2}$ showed excellent inhibition of $\mathrm{AChE}\left(\mathrm{IC}_{50}=0.029 \pm 0.003 \mu \mathrm{M}\right), \mathrm{BuChE}$ $\left(\mathrm{IC}_{50}=0.039 \pm 0.003 \mu \mathrm{M}\right)$ and selective MAO-A inhibition $\left(\mathrm{IC}_{50}=10.1 \pm 1.1 \mu \mathrm{M}\right)$. Compound 72 also showed metal chelating and antioxidant properties. The potency of compound $\mathbf{7 2}$ for cholinesterases was linked to the appropriate distance between the aromatic part and basic centre which are necessary for interaction with PAS, mid-gorge and CAS of AChE. Compound $\mathbf{7 2}$ is the bigger derivative in this series and cyano group can interact with mid gorge because of the correct length (Wu et al., 2016).

\section{Attachment of benzyl piperidine and benzyl piperazine with condensed heterocyclic rings}

Vila et al. (2016) carried out the synthesis of donepezil analogues in which the indanone part of donepezil was replaced by the phthalazinone nucleus and the phthalazinone was connected to the $\mathrm{N}$-benzylpiperidine fragment through the alkyl chain of two to three carbons. Compound $\mathbf{7 3}$ was prominently active and found to be the equipotent inhibitor of $\mathrm{AChE}$ and BuChE having $\mathrm{IC}_{50}$ values of $3.45 \pm 0.23 \mu \mathrm{M}$ and $5.50 \pm 0.37 \mu \mathrm{M}$. Compound 73 (Figure 11) contains p-toluyl group at position \# 4 of the phthalazinone ring which gives an additional hydrophobic interaction with cholinesterases. Docking studies also showed dual binding of this compound with $\mathrm{AChE}$ as well as with BuChE (Vila et al., 2016). Pudlo et al. connected quinoline carboxamide to the benzylpiperidine to produce the new hybrid molecules. These compounds exhibited the better inhibition of AChE as compared to BuChE. Compounds $\mathbf{7 4}$ and $\mathbf{7 5}$ were most active having
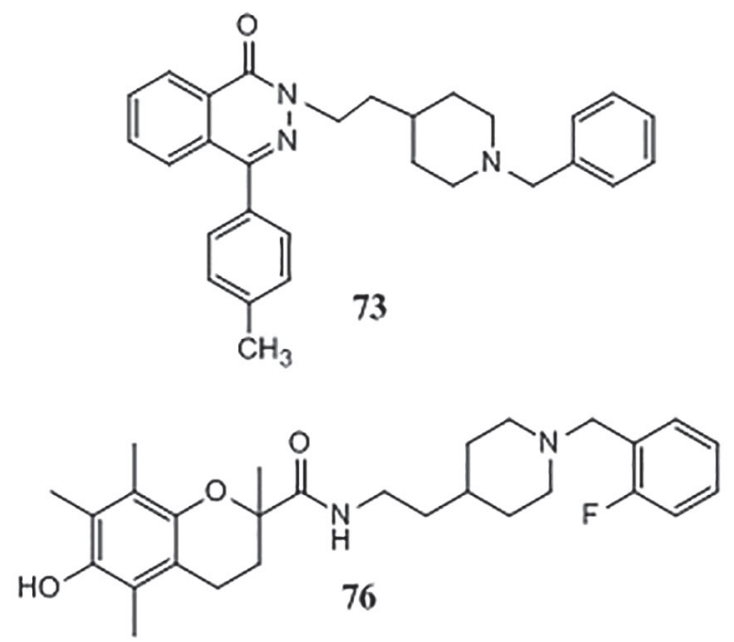

$\mathrm{IC}_{50}$ values of $0.11 \pm 0.03 \mu \mathrm{M}$ and $0.48 \pm 0.14 \mu \mathrm{M}$. Compound 75 also showed highest antioxidant activity $\left(\mathrm{EC}_{50}=12.2 \pm 0.4 \mu \mathrm{M}\right)$ and it contains catechol ring. Catechol ring was found to be important for antioxidant activity. Docking studies of compound $\mathbf{7 5}$ showed that phenyl group formed $\pi-\pi$ interactions with CAS, piperidinium interacted with gorge and quinoline part was attached with PAS of AChE (Pudlo et al., 2014). Synthesis of donepezil-Trolox hybrid molecules was reported by Cai et al. (2017). These compounds demonstrated activity against AChE and MAO-B enzymes. The most potent compound $\mathbf{7 6}$ showed inhibition of human $\mathrm{AChE}$ and MAO-B with $\mathrm{IC}_{50}$ values of $0.54 \mu \mathrm{M}$ and $4.3 \mu \mathrm{M}$ respectively. This compound also showed significant antioxidant activity $\left(\mathrm{IC}_{50}=41.33 \mu \mathrm{M}\right)$ and less hepatotoxicity to cell lines PC12, HePG2 and BV-2 (Cai et al., 2017). $N$-benzylpiperidine fragment of donepezil and melatonin were fused together to produce the new molecules. Most of the compounds showed higher inhibition of $\mathrm{BuChE}$ as compared to AChE. Compound 77 was the excellent inhibitor of electric $\mathrm{AChE}$ and equine BuChE having $\mathrm{IC}_{50}$ values of $193 \mathrm{nM}$ and $73 \mathrm{nM}$. This compound also displayed $\mathrm{A} \beta$ aggregation (56.3\%) inhibition and antioxidant activities (3.28 Trolox equivalent). It also showed the capacity to penetrate into CNS. Molecular modeling studies showed that compound $\mathbf{7 7}$ interacted with CAS and PAS of AChE (Wang et al., 2016).

Ismail et al. (2012b) carried out the synthesis of donepezil derivatives in which the indanone part of donepezil was substituted by tetrahydrobenzo[b] thiophine ring having carbonyl group at position \# 3 of tetrahydrobenzo[b]thiophine. Acetamide group was introduced as a linker between the tetrahydrobenzo[b] thiophine and benzylpiperidine. Compounds $\mathbf{7 8}$ and $\mathbf{7 9}$<smiles>[R]c1cc2c(cc1[R])C(O)=C(C(=O)NCC1CCN(Cc3ccccc3)CC1)CN2</smiles><smiles>O=C(CCc1c[nH]c2ccccc12)NN=C1CCN(Cc2ccccc2)CC1</smiles>

FIGURE 11 - Donepezil derivatives having condensed heterocyclic rings. 


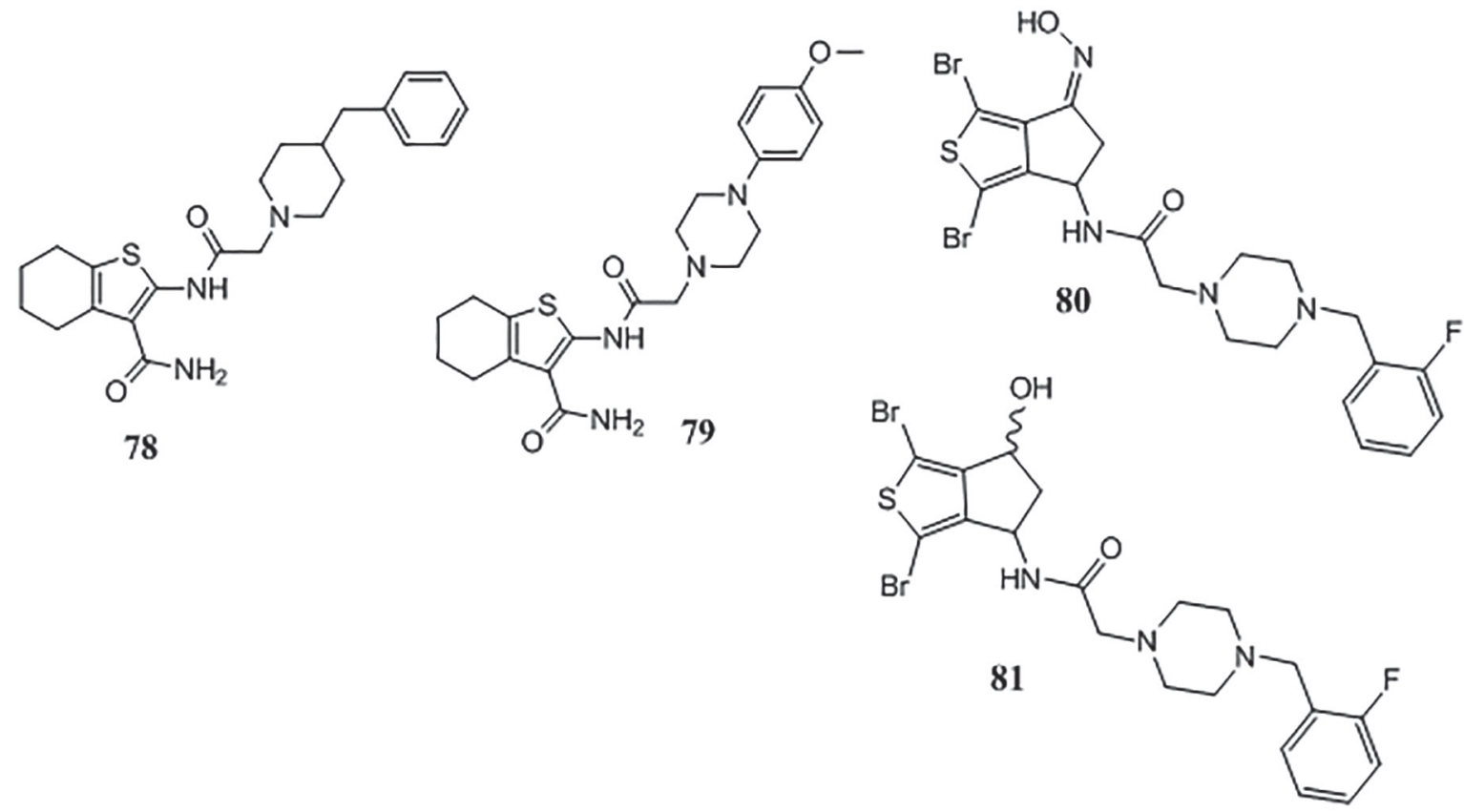

FIGURE 12 - Donepezil derivatives having condensed heterocyclic rings.

(Figure 12) exhibited prominent inhibition (56.67\%, $60 \%$ for $\mathbf{7 8}$ and 79 ) of $\mathrm{AChE}$ which was better than the standard drug donepezil (40\%). In molecular docking studies, compound $\mathbf{7 8}$ presented strong hydrogen bonding than donepezil, which may be due to the amide group (Ismail et al., 2012b). Omran et al. (2005) carried out the synthesis of new indanones and thiaindanones derivatives and evaluated their $\mathrm{AChE}$ inhibitory activity. Compound $\mathbf{8 0}$ exhibited excellent inhibition of $\mathrm{AChE}$ having an $\mathrm{IC}_{50}$ value of $0.06 \mu \mathrm{M}$ as compared to donepezil $\left(\mathrm{IC}_{50}=0.02 \mu \mathrm{M}\right)$. It contains oxime group in the thiaindanone part and thiaindanone is attached to 2-fluorobenzyl piperazine through acetamide linker. Molecular modeling studies were also carried out and it was observed that fluorine atom at the ortho position of the benzyl group amplified the $\pi-\pi$ interaction with the AChE enzyme (Omran et al., 2005). Omran et al. (2008) carried out further modification and compound $\mathbf{8 1}$ was the most active inhibitor of $\mathrm{AChE}$ showing an $\mathrm{IC}_{50}$ value of $0.5 \mu \mathrm{M}$. It was observed that the replacement of the piperazine ring leads to the formation of inactive compounds. Replacement of hydroxyl group of this molecule with the bromine or fluorine produced less active compounds (Omran et al., 2008).

\section{DISCUSSION}

A literature review of donepezil showed that benzylpiperidine part of donepezil can be replaced with benzylpyridine, benzylpiperazine, pyridyl methylpiperidine, aniline and phenylpiperazine motifs with the retention of activity as anti-Alzheimer agents. Replacement of benzylpiperidine with unsubstituted piperidine produced less active compounds. 3-Hydroxy-6(piperidin-1-ylmethyl)picolinaldehyde oxime derivatives were found to be reactivator of the AChE. Alkylamine, carboxamide and acylhydrazone are most commonly used linkers in these molecules. Attachment of benzylpiperidine with heterocyclic rings such as pyridine showed $\mathrm{AChE}$ and BuChE inhibitory activity while the picolinamide derivative showed MAO inhibition in addition to cholinesterase inhibitory activity. Benzylpiperidine part of donepezil has also been attached with condensed heterocyclic rings such as phthalazine, quinoline, tetrahydrobenzothiophine, indole and Trolox and these molecules showed anti-Alzheimer activities. Propargylamine derived compounds also exhibited MAO inhibition in addition to cholinesterase inhibition properties. In some derivatives, indanone part has been replaced with tetralone, oxindole, and phthalimide with retention of activity. Hybrid molecules of donepezil with ferulic acid showed higher BuChE inhibitory activity as compared to AChE inhibitory activity. These compounds also showed antioxidant as well as A $\beta$ aggregation inhibitory activities. Hybrid molecules of donepezil with tacrine produced compounds having $\mathrm{AChE}$ and $\mathrm{BuChE}$ inhibition. Donepezil hybrid molecules with natural compounds like flavonoids, coumarins, and curcumin presented antioxidant and MAO inhibitory activities in addition to cholinesterase inhibition. Amino acid derived compounds of donepezil showed dual inhibition of $\mathrm{AChE}$ 
and $\mathrm{BuChE}$ enzymes. In this review, we have summarized the recent research progress of donepezil derived antiAlzheimer agents. This review can help to provide some useful information for organic and medicinal chemists working in this field.

\section{REFERENCES}

Alonso D, Dorronsoro I, Rubio L, Munoz P, García-Palomero E, Del Monte M, et al. Donepezil-tacrine hybrid related derivatives as new dual binding site inhibitors of AChE. Bioorg Med Chem. 2005;13(24):6588-6597.

Azzouz R, Peauger L, Gembus V, Ţînţaş M-L, Sopková-de Oliveira Santos J, Papamicaël C, et al. Novel donepezil-like $\mathrm{N}$-benzylpyridinium salt derivatives as AChE inhibitors and their corresponding dihydropyridine "bio-oxidizable" prodrugs: Synthesis, biological evaluation and structure-activity relationship. Eur J Med Chem. 2018;145:165-90.

Bar-Am O, Amit T, Weinreb O, Youdim MB, Mandel S. Propargylamine containing Compounds as modulators of proteolytic cleavage of amyloid protein precursor: involvement of MAPK and PKC activation. J Alzheimer's Dis. 2010;21(2):361-371.

Bautista-Aguilera OM, Esteban G, Bolea I, Nikolic K, Agbaba D, Moraleda I, et al. Design, synthesis, pharmacological evaluation, QSAR analysis, molecular modeling and ADMET of novel donepezil-indolyl hybrids as multipotent cholinesterase/ monoamine oxidase inhibitors for the potential treatment of Alzheimer's disease. Eur J Med Chem. 2014;75:82-95.

Benchekroun M, Ismaili L, Pudlo M, Luzet V, Gharbi T, Refouvelet B, et al. Donepezil-ferulic acid hybrids as antiAlzheimer drugs. Future Med Chem. 2015;7(1):15-21.

Birks J, Harvey RJ. Donepezil for dementia due to Alzheimer's disease. Cochrane Database Syst Rev. 2006;(1):Cd001190.

Bolea I, Juárez-Jiménez J, de los Ríos CB, Chioua M, Pouplana RN, Luque FJ, et al. Synthesis, biological evaluation, and molecular modeling of donepezil and $\mathrm{N}-[(5-$ (benzyloxy)-1methyl-1 H-indol-2-yl) methyl]-N-methylprop-2-yn-1-amine hybrids as new multipotent cholinesterase/monoamine oxidase inhibitors for the treatment of Alzheimer's disease. J Med Chem. 2011;54(24):8251-8270.

Bush AI. Drug development based on the metals hypothesis of Alzheimer's disease. J Alzheimers Dis. 2008;15(2):223-240.
Cai P, Fang S-Q, Yang X-L, Wu J-J, Liu Q-H, Hong H, et al. Rational design and multibiological profiling of novel donepezil-trolox hybrids against Alzheimer's disease, with cholinergic, antioxidant, neuroprotective, and cognition enhancing properties. ACS Chem Neurosci. 2017;8(11):24962511.

Camps P, Formosa X, Galdeano C, Gómez T, Munoz-Torrero D, Scarpellini M, et al. Novel donepezil-based inhibitors of acetyland butyrylcholinesterase and acetylcholinesterase-induced $\beta$-amyloid aggregation. J Med Chem. 2008;51(12):3588-3598.

Cheung J, Rudolph MJ, Burshteyn F, Cassidy MS, Gary EN, Love J, et al. Structures of human acetylcholinesterase in complex with pharmacologically important ligands. J Med Chem. 2012;55(22):10282-10286.

Costanzo P, Cariati L, Desiderio D, Sgammato R, Lamberti A, Arcone R, et al. Design, synthesis, and evaluation of donepezillike compounds as AChE and BACE-1 inhibitors. ACS Med Chem Lett. 2016;7(5):470-475.

David O, Varun KD, Ying S, Debomoy KL, Nigel HG, Jack TR, et al. N-Methyl D-Aspartate (NMDA) Receptor antagonists and memantine treatment for Alzheimer's disease, vascular dementia and Parkinson's disease. Curr Alzheimer Res. 2012;9(6):746-758.

Dias KST, de Paula CT, dos Santos T, Souza IN, Boni MS, Guimarães MJ, et al. Design, synthesis and evaluation of novel feruloyl-donepezil hybrids as potential multitarget drugs for the treatment of Alzheimer's disease. Eur J Med Chem. 2017;130:440-457.

Doody RS, Cummings JL, Farlow MR. Reviewing the role of donepezil in the treatment of Alzheimer's disease. Curr Alzheimer Res. 2012;9(7):773-781.

Gella A, Durany N. Oxidative stress in Alzheimer disease. Cell Adhesion Migration. 2009;3(1):88-93.

Ignasik M, Bajda M, Guzior N, Prinz M, Holzgrabe U, Malawska B. Design, synthesis and evaluation of novel 2-(Aminoalkyl)-isoindoline-1, 3-dione derivatives as dualbinding site acetylcholinesterase inhibitors. Arch Pharm. 2012;345(7):509-516.

Ismail MM, Kamel MM, Mohamed LW, Faggal SI. Synthesis of new indole derivatives structurally related to donepezil and their biological evaluation as acetylcholinesterase inhibitors. Molecules. 2012a;17(5):4811-4823. 
Ismail MM, Kamel MM, Mohamed LW, Faggal SI, Galal MA. Synthesis and biological evaluation of thiophene derivatives as acetylcholinesterase inhibitors. Molecules. 2012b;17(6):72177231.

Koehn FE, Carter GT. The evolving role of natural products in drug discovery. Nat Rev Drug Discov. 2005;4(3):206-220.

Korabecny J, Dolezal R, Cabelova P, Horova A, Hruba E, Ricny $\mathrm{J}$, et al. 7-MEOTA-donepezil like compounds as cholinesterase inhibitors: Synthesis, pharmacological evaluation, molecular modeling and QSAR studies. Eur J Med Chem. 2014;82:426438 .

Lan J-S, Zhang T, Liu Y, Yang J, Xie S-S, Liu J, et al. Design, synthesis and biological activity of novel donepezil derivatives bearing N-benzyl pyridinium moiety as potent and dual binding site acetylcholinesterase inhibitors. Eur J Med Chem. 2017;133:184-196.

Leon R, Garcia AG, Marco-Contelles J. Recent advances in the multitarget-directed ligands approach for the treatment of Alzheimer's disease. Med Res Rev. 2013;33(1):139-189.

Li F, Wang Z-M, Wu J-J, Wang J, Xie S-S, Lan J-S, et al. Synthesis and pharmacological evaluation of donepezil-based agents as new cholinesterase/monoamine oxidase inhibitors for the potential application against Alzheimer's disease. J Enzyme Inhib Med Chem. 2016;31(Supl 3):41-53.

Meng F-C, Mao F, Shan W-J, Qin F, Huang L, Li X-S. Design, synthesis, and evaluation of indanone derivatives as acetylcholinesterase inhibitors and metal-chelating agents. Bioorg Med Chem Lett. 2012;22(13):4462-4466.

Mishra CB, Kumari S, Manral A, Prakash A, Saini V, Lynn $\mathrm{AM}$, et al. Design, synthesis, in-silico and biological evaluation of novel donepezil derivatives as multi-target-directed ligands for the treatment of Alzheimer's disease. Eur J Med Chem. 2017;125:736-750.

Misik J, Korabecny J, Nepovimova E, Cabelova P, Kassa J. The effects of novel 7-MEOTA-donepezil like hybrids and $\mathrm{N}$-alkylated tacrine analogues in the treatment of quinuclidinyl benzilate-induced behavioural deficits in rats performing the multiple T-maze test. Biomed Pap Med Fac Univ Palacky Olomouc Czech Repub. 2015;159(4):547-553.
Mohammadi-Farani A, Ahmadi A, Nadri H, Aliabadi A. Synthesis, docking and acetylcholinesterase inhibitory assessment of 2-(2-(4-Benzylpiperazin-1-yl) ethyl) isoindoline-1, 3-dione derivatives with potential anti-Alzheimer effects. DARU. 2013;21(1):47.

Monjas L, Arce M P, León R, Egea J, Pérez C, Villarroya M, et al. Enzymatic and solid-phase synthesis of new donepezil-based L-and D-glutamic acid derivatives and their pharmacological evaluation in models related to Alzheimer's disease and cerebral ischemia. Eur J Med Chem. 2017;130:60-72.

Naj AC, Jun G, Beecham GW, Wang L-S, Vardarajan BN, Buros $\mathrm{J}$, et al. Common variants at MS4A4/MS4A6E, CD2AP, CD33 and EPHA1 are associated with late-onset Alzheimer's disease. Nat Genet. 2011;43(5):436.

Nan D-D, Gan C-S, Wang C-W, Qiao J-P, Wang X-M, Zhou J-N. 6-Methoxy-indanone derivatives as potential probes for $\beta$-amyloid plaques in Alzheimer's disease. Eur J Med Chem. 2016;124:117-128.

Omran Z, Cailly T, Lescot E, Sopkova-de Oliveira Santos J, Agondanou J-H, Lisowski V, et al. Synthesis and biological evaluation as AChE inhibitors of new indanones and thiaindanones related to donepezil. Eur J Med Chem. 2005;40(12):1222-1245.

Omran Z, Stiebing S, Godard A-M, Sopkova-De Oliveira-Santos J, Dallemagne P. Synthesis and biological evaluation of new Donepezil-like Thiaindanones as AChE inhibitors. J Enzyme Inhib Med Chem. 2008;23(5):696-703.

Özer EÖ, Tan OU, Ozadali K, Küçükkılınç T, Balkan A, Uçar G. Synthesis, molecular modeling and evaluation of novel $\mathrm{N}^{\prime}-2-(4-$ benzylpiperidin-/piperazin-1-yl) acylhydrazone derivatives as dual inhibitors for cholinesterases and $\mathrm{A} \beta$ aggregation. Bioorg Med Chem Lett. 2013;23(2):440-443.

Pudlo M, Luzet V, Ismaïli L, Tomassoli I, Iutzeler A, Refouvelet B. Quinolone-benzylpiperidine derivatives as novel acetylcholinesterase inhibitor and antioxidant hybrids for Alzheimer Disease. Bioorg Med Chem. 2014;22(8):2496-2507.

Renou J, Dias J, Mercey G, Verdelet T, Rousseau C, Gastellier A-J, et al. Synthesis and in vitro evaluation of donepezil-based reactivators and analogues for nerve agent-inhibited human acetylcholinesterase. RSC Advances. 2016;6(22):17929-17940. 
Rizzo S, Bartolini M, Ceccarini L, Piazzi L, Gobbi S, Cavalli A, et al. Targeting Alzheimer's disease: Novel indanone hybrids bearing a pharmacophoric fragment of AP2238. Bioorg Med Chem. 2010;18(5):1749-1760.

Rodríguez-Franco MI, Fernández-Bachiller MI, Pérez C, Castro A, Martínez A. Design and synthesis of N-benzylpiperidinepurine derivatives as new dual inhibitors of acetyl-and butyrylcholinesterase. Bioorg Med Chem. 2005;13(24):67956802.

Sağlık BN, Ilgın S, Özkay Y. Synthesis of new donepezil analogues and investigation of their effects on cholinesterase enzymes. Eur J Med Chem. 2016;124:1026-1040.

Samadi A, de la Fuente Revenga M, Pérez C, Iriepa I, Moraleda I, Rodríguez-Franco M I, et al. Synthesis, pharmacological assessment, and molecular modeling of 6-chloro-pyridonepezils: New dual AChE inhibitors as potential drugs for the treatment of Alzheimer's disease. Eur J Med Chem. 2013;67:64-74.

Samadi A, Estrada M, Pérez C, Rodríguez-Franco M I, Iriepa I, Moraleda I, et al. Pyridonepezils, new dual AChE inhibitors as potential drugs for the treatment of Alzheimer's disease: Synthesis, biological assessment, and molecular modeling. Eur J Med Chem. 2012;57:296-301.

Sang Z, Pan W, Wang K, Ma Q, Yu L, Yang Y, et al. Design, synthesis and evaluation of novel ferulic acid-O-alkylamine derivatives as potential multifunctional agents for the treatment of Alzheimer's disease. Eur J Med Chem. 2017;130:379-392.

Scarpini E, Scheltens P, Feldman H. Treatment of Alzheimer's disease: current status and new perspectives. Lancet Neurol. 2003;2(9):539-547.

Selkoe DJ, Podlisny MB. Deciphering the genetic basis of Alzheimer's disease. Annu Rev Genom Hum G. 2002;3(1):6799.

Sepsova V, Karasova JZ, Tobin G, Jun D, Korabecny J, Cabelova $\mathrm{P}$, et al. Cholinergic properties of new 7-methoxytacrinedonepezil derivatives. Gen Physiol Biophys. 2015;34:189-200.

Shen Y, Zhang J, Sheng R, Dong X, He Q, Yang B, et al. Synthesis and biological evaluation of novel flavonoid derivatives as dual binding acetylcholinesterase inhibitors. J Enzyme Inhib Med Chem. 2009;24(2):372-380.
Song Y-H, Jo B-S. Synthesis of new alkylene-linked donepezilaminothienoquinoline hybrid related derivatives. Bull Korean Chem Soc. 2009;30(4):969-971.

Soukup O, Jun D, Karasova J, Patocka J, Musilek K, Korabecny $\mathrm{J}$, et al. A resurrection of 7-MEOTA: A comparison with tacrine. Curr Alzheimer Res. 2013;10:893-906.

Talesa VN. Acetylcholinesterase in Alzheimer's disease. Mech Ageing Dev. 2001;122(16):1961-1969.

Viegas FPD, de Freitas Silva M, da Rocha MD, Castelli MR, Riquiel MM, Machado RP, et al. Design, synthesis and pharmacological evaluation of N-benzyl-piperidinyl-arylacylhydrazone derivatives as donepezil hybrids: Discovery of novel multi-target anti-alzheimer prototype drug candidates. Eur J Med Chem. 2018;147:48-65.

Vila N, Besada P, Viña D, Sturlese M, Moro S, Terán C. Synthesis, biological evaluation and molecular modeling studies of phthalazin-1 (2 H)-one derivatives as novel cholinesterase inhibitors. RSC Advances. 2016;6(52):46170-46185.

Wang J, Wang Z-M, Li X-M, Li F, Wu J-J, Kong L-Y, et al. Synthesis and evaluation of multi-target-directed ligands for the treatment of Alzheimer's disease based on the fusion of donepezil and melatonin. Bioorg Med Chem. 2016;24(18):43244338 .

Wang L, Esteban G, Ojima M, Bautista-Aguilera O M, Inokuchi T, Moraleda I, et al. Donepezil+ propargylamine+ 8-hydroxyquinoline hybrids as new multifunctional metalchelators, ChE and MAO inhibitors for the potential treatment of Alzheimer's disease. Eur J Med Chem. 2014;80:543-561.

Wang Z-M, Cai P, Liu Q-H, Xu D-Q, Yang X-L, Wu J-J, et al. Rational modification of donepezil as multifunctional acetylcholinesterase inhibitors for the treatment of Alzheimer's disease. Eur J Med Chem. 2016;123:282-297.

Wu M-Y, Esteban G, Brogi S, Shionoya M, Wang L, Campiani $\mathrm{G}$, et al. Donepezil-like multifunctional agents: design, synthesis, molecular modeling and biological evaluation. Eur J Med Chem. 2016;121:864-879.

Xie S-S, Lan J-S, Wang X, Wang Z-M, Jiang N, Li F, et al. Design, synthesis and biological evaluation of novel donepezilcoumarin hybrids as multi-target agents for the treatment of Alzheimer's disease. Bioorg Med Chem. 2016;24(7):1528-1539. 
Xu W, Wang X-B, Wang Z-M, Wu J-J, Li F, Wang J, et al. Synthesis and evaluation of donepezil-ferulic acid hybrids as multi-target-directed ligands against Alzheimer's disease. Med Chem Comm. 2016;7(5):990-998.

Yan J, Hu J, Liu A, He L, Li X, Wei H. Design, synthesis, and evaluation of multitarget-directed ligands against Alzheimer's disease based on the fusion of donepezil and curcumin. Bioorg Med Chem. 2017;25(12):2946-2955.

Yerdelen KO, Koca M, Anil B, Sevindik H, Kasap Z, Halici $Z$, et al. Synthesis of donepezil-based multifunctional agents for the treatment of Alzheimer's disease. Bioorg Med Chem Lett. 2015;25(23):5576-5582.
Zhu Y, Xiao K, Ma L, Xiong B, Fu Y, Yu H, et al. Design, synthesis and biological evaluation of novel dual inhibitors of acetylcholinesterase and $\beta$-secretase. Bioorg Med Chem. 2009;17(4):1600-1613.

Żurek E, Szymański P, Mikiciuk-Olasik E. Synthesis and biological activity of new donepezil-hydrazinonicotinamide hybrids. Drug Res. 2013;34(3):137-144.

Received for publication on $25^{\text {th }}$ April 2018 Accepted for publication on $23^{\text {rd }}$ October 2018 